\title{
Hyperreality in Dance Education and Challenges in Teaching Dance Education at Schools
}

\author{
Kuswarsantyo $^{1 *}$ \\ ${ }^{1}$ Yogyakarta State University, Yogyakarta, Indonesia \\ *Corresponding author. Email: kuswarsantyo@uny.ac.id
}

\begin{abstract}
Whether art teachers are required to make use of existing materials without the need to develop their works using their own ideas is questionable. If the purpose is teaching crafts, we can find so many teachers who never create any work. However, in terms of art education, teaching dance only to pursue a skill is not appropriate. Moreover, as art education is taught in formal schools, there is a need to anticipate hyperreality. Thus, the schools can produce graduates with cognitive, psychomotor, and affective competencies. Determining appropriate learning objectives is a must, and the goals should involve the development of teacher skills in developing learning models. Then, teachers should be able to develop the students' ability to appreciate the aesthetics values and to instill character values. Thus, the teaching materials that need to be mastered include 1) arts to be practiced contextually, 2) stimulation to get trust and the ability to express an artistic idea, and 3) stimulation to improve imagination and creation.
\end{abstract}

Keywords: Hyperreality, Character Values, Aesthetics Values, Dance Education

\section{INTRODUCTION}

Hyperreality is the inability to distinguish between reality and fantasy. In other words, truth, authenticity, falsehood, facts, or lies are blurred. According to Amir Piliang, hyperreality is a world that keeps on developing, growing, moving, and changing without purpose (fatality), without foundation (anti-foundation), without control, without code (social code), and without meaning (meaningless) [11]. This makes originality blurred in the world of hyperreality. Everything can arise without roots and certainty. Furthermore, hyperreality is a world that refers to itself and emerges with itself. This condition causes hyperreality behavior in people's consumption. Muhammad Azwar states that the state of hyperreality makes modern society excessive in consuming something with no specific purpose and out of necessity only because of trends [1].

The hyperreality problems are present in the educational field, especially in the dance education discipline. How to anticipate the direction and learning goals to be in line with the curriculum and learning outcome is our problem. The art of dance shown by the dancer is closely related to supporting factors that shape the art characteristics. The expression of art is based on the emotion of the artists. Thus, there definitely be a problem if art teachers as artists provide teaching material without considering the students' psychological aspect and development. Thus, making use own creation to teach is mandatory.
In this paper, the researcher tries to elaborate the problems faced by art teachers during the hyperreality era.

1. What is the future strategy to provide awareness to prospective teachers and teachers to understand the concept of dance education comprehensively?

2. What dance material is in accordance with the students' characters?

3. What approaches can be used to form attitudes while practicing art?

4. What behavior impacts are expected from dance education?

5. Are teachers able to adopt dances based on nature to technology, based on animation to real dance, and vice versa?

6. How do teachers improve the student's ability to search for digital information related to dances?

\section{INTRODUCING DANCE EDUCATION TO CHILDREN}

Strategies or techniques to introduce dance to children should be implemented because children tend to get bored of learning dance. Thus, dance teachers should fully understand what a dance is, how the dance is performed, whom is it for, and where the dance is performed. These four principles are the basis of introducing dance to children. Early understanding is necessary, so that dance is not only considered an sich 
skill. The provisional assumption of those who say that dance education is about practices is unfounded because dance has a very complex historical background related to the cultural journey of the nation. Besides, teachers must be able to show that dance is one of the sources of education that is effective for children. Dance education is not aimed at learning only the movement, but also attitudes, and discipline.

Dewantara stated that children's dance will sharpen their logical thinking, improve sensitivity, and develop a sense of independence [4]. Moreover, Rudolph Steiner said that the influence of rhythm or wiromo in dance accompaniment can be used as a medium to achieve a harmonious attitude. The achievement of harmony in dance learning serves as the basis for forming good character education. It is expected that dance education may produce good humans and may lead to dignified culture. Character building becomes an important and strategic strategy because characters are related to morals. Good characters are reflected in noble attitudes [9]

From the explanation above, it is indicated that dance education is a means of developing children's characters. Elementary school students need to express their ideas in various art forms, so they are getting used to it in the future, and art education plays a very important role in human life.

Elementary school teachers have a very vital role to filter foreign cultural influences that are incompatible with the Indonesian culture. Art as part of the cultural content is an expression for artists thus accommodating symbolic meanings of movements. In order to fully understand what art is, we should understand the supporting factors of the art characteristics. The expressions of art are based on the emotion of the artists. Thus, there definitely be a problem if teachers as artists provide teaching material without considering the students' psychological aspect and development. Making use of own creation to teach is mandatory.

\section{DANCE MATERIAL FOR CHILDREN}

Before discussing the basic dance movement material for children, it is necessary to know in advance the purpose of the dance taught to children in order to achieve the goals of teaching dance.

General Purpose:

a. Developing nationalism

b. Improving the aesthetics sense

c. Providing guidance to children to express their aesthetic sense

d. Sharping their logical thinking, improve sensitivity, and develop a sense of independence
Specific Purpose:

a. Providing a place for expressing children's ideas and feeling through movements

b. Improving art appreciation

c. Providing basic dance skills

From these objectives, it is clear that the goal of learning dance is not a top priority. What is more important is the aspect behind dance education in relation to issues of character building for children. For this reason, children should not be forced to accept teaching material that is not appropriate for their age level because it is harmful to psychological development. Dance teaching material for children must be able to stimulate and develop imagination and provide freedom for children to explore [10].

According to Bourdieu, past experiences in the form of schemes of perception thought, and action, especially all formal rules and explicit norms ensure the suitability of practices over time [3]. This opinion is relevant to efforts to present teaching materials that must be updated from time to time. For this reason, dance education teaching materials in schools should always be able to follow and adjust children's needs which are in accordance with the students' ages.

The dance materials for children are classified as follows.

1. Dance arranged based on children's play (games)

2. Dance arranged based on song lyrics

3. Dance arranged based on songs

4. Adaptation of daily activity (for the first to third grades of elementary school)

5. Adaptation of traditional dance

6. Traditional dance arranged based on childrens' souls

7. Traditional dance adapted to the children's abilities (for the fourth to sixth grades of elementary school).

To teach dance effectively to children, we need to know their ages. To provide material for grades one to three of elementary school, the imitation method may be implemented. This kind of method allows children to move and improvise freely but focus on the rhythmic. Meanwhile, for children in grades four to six, the same method may be implemented but the quality and accuracy of movements should become the focus.

\section{DANCE EDUCATION AT SCHOOLS}

The dance lessons at schools can be used as a measure of education. This fact should become one of 
the bases of curriculum development. Dance education which contains educational values should be able to build children's characters. Learning the arts properly and thoroughly is an implementation of learning character. Ki Hajar Dewantara once stated that the existence of art lessons in schools aims to influence children's mental development and enhance their aesthetic sensitivity. In other words, art education may shape children into civilized and cultured humans [5].

Balancing logical thinking and feelings through artistic activities at school will contribute to the overall behavior of students both in cognitive, affective, and psychomotor aspects. It is often found that children express their emotions irrationally. Personal problems may lead to uncompromised fights, and then brutalism is present at schools. This condition is really serious as students do not need to face such a problem. The problem should be solved immediately.

However, art education at schools can at least suppress excessive emotional attitudes. With refinement, tenderness, and rhythmic harmony as outlined in a series of dance movements, students' feelings are touched. Making students sit in a room with traditional music is some kind of psychotherapy that is effective to build children's characters

To optimize the role and function of art education at schools, school leaders (principals) need to have common visions and missions because, with a common perspective on the importance of art education, the learning goals will easily be achieved. The shared perspective about the nature of arts should be introduced to parents, students (not to dancers), singers, painters, or musicians because children improve their sense of arts at schools.

The moral values conveyed can link art with history, art with philosophical issues of beauty, and so on. To master this, teachers must strive to improve their own abilities so that what is conveyed does not actually obscure the main mission of fostering children's love with arts. With this practical approach, children are expected to be able to respond positively to efforts to return art education to schools. Whether we realize it or not, children (students) are an asset to the nation. They are the successors of the Indonesian nation. Therefore, it is our responsibility to equip children with various moral values that are in accordance with the personality and culture of the Indonesian people.

Art as part of cultural content is a valuable asset to improve the image (identity) of a nation. With its various branches, art has proven itself that it is able to show characteristics of the supporting community. Therefore, arts cannot be separated from psychological, sociological, historical, or cultural aspects related to human life in certain communities. This means that someone's life within a community is closely related to community life. Arts and community life can influence each other both in positive and negative ways. It depends on our point of view in seeing the world and our goals to be achieved in arts.

Starting from that goal, art education serves as the basis for understanding the very high content of education to be used as a medium for children's character building. In terms of philosophy, symbolic meanings can be associated with children's behavior in daily life. Moral teachings in traditional arts seem to be ignored by art teachers, so they are always underestimated. They are seen only as practices that do not support children's learning achievement. This lack of in-depth basic thinking about knowledge of traditional arts is what puts the position of art education in public schools closer to its "grave". Teachers should play an active role in elevating the position of art education to a higher level. Teachers need to develop their competence to improve the image of art education which builds children's characters.

\section{VALUES IN ART EDUCATION TO BUILD CHARACTER}

Character education is related to teaching values. The values in the art are not only aesthetic values, but other values of life such as honesty, courage, respect, responsibility, and fairness. Those values should be possessed by humans and often associated with character education. Black elaborated character education into three elements [2], namely:

1. A common core of shared or universal values

2. The belief that there are rational, objectively valid, universally accepted qualities to which people of all nations, creeds, races, socioeconomic statuses, and ethnicity subscribe

3. The belief that traits (qualities) transcend political persuasions as well as religious and ethnic differences.

The three elements above emphasize universal values and beliefs in diversity. Black suggested that to include character education in schools, the first obligation is to identify universal values that will be the focus of the program and make a commitment to teaching these values. The core values shared by schools in the United States include honesty, courage, responsibility, respect, fairness, mutual trust, loyalty, and compassion.

Dewantara formulated three basic principles that have the values of life, namely "Ing Ngarsa Sung Tulada, Ing Madya Mangun Karsa, Tut Wuri Handayani" [4]. These values mean exemplary, passion for work, and support. Ki Hajar Dewantara expressed his views on the values of life in studying art. In the book entitled "Karya Ki Hajar Dewantara" published in 
1994 [4], Dewantara stated that in learning Gending (Javanese musical instrument), people do not only obtain knowledge but also develop their senses because they keep on improving their rhythmic, aesthetic, and ethical senses.

Dewantara expressed that this sensitivity is like how religious leaders and priests make use of music [4]. Music improves the sense of religiosity and shapes morals. In addition, Dewantara explained that dance can teach politeness, civility (morals), and order. In other words, music and dance are closely related to the regular rhythm which will have an impact on order in life, feelings of pleasure, and happiness. Dewantara also argued that teaching Gending or art is an effort to instill a sense of pride in the nation's beautiful and noble culture. The values mentioned by Dewantara are the result or benefit of learning art, and values themselves are not directly planned to be taught.

The era of globalization is not a reason to not preserve the traditional arts. By preserving the traditional art of children's games, we will also make patterns of people's lives which is increasingly heterogeneous. However, childhood must be maintained. What children do during childhood will contribute to the formation of attitudes, as well as improve sensitivity and politeness. Although it is impossible to be back to the 70s', the atmosphere that once grew among the children in the past, can be brought up again.

Art Education in public schools (from elementary schools to junior and senior high schools) can introduce children to their world, especially kindergarten and elementary schools. Unfortunately, there are still many intelligent people who think that art education is not important for children. Various arguments are given to deny the importance of art education in schools because it interferes with other subjects that are considered more prospective.

Most teachers and school principals forget that what is delivered in art education is not widely known. If we examine it objectively, the meaning contained in art education is very broad and profound. This fact is what currently does not benefit the position of art education in public schools. It is ideal when scientific advancement is supported by other subjects in order to master cognitive, affective, and psychomotor competencies.

Considering the importance of art education for children, organizing the Children's Game Festival can function as an initial filter of foreign cultural influences that are not in accordance with our life and culture. Making art education a compulsory local content subject is the best and wisest way. In local content subjects, each region may determine its own prioritized materials to be taught to children. Thus, it will contribute more to the formation of children's attitudes according to their own environmental conditions.

Art is an expression. In order to comprehensively understand art, supporting factors that shape the art characteristics should be explored. The expression of art is based on the emotion of the artists. Thus, there definitely be a problem if art teachers as artists provide teaching material without considering the students' psychological aspect and development. Thus, making use own creation to teach is mandatory. It is assumed that art education for children is very crucial to anticipate certain behaviors.

Some of these signals support the argument that art education is after all indispensable in general education. The problem that arises in this certain field is why art education is still considered unnecessary. It is probably due to textual or partial understanding. Now art education must be understood contextually (holistically). Thus, the future orientation obtained from attending art education lessons at schools will provide more meaning and benefits for the students. In other cases, the phenomenon of deviating children's behavior towards the environment, such as wall painting, or hair dyeing, can be used as an indication that in the educational process there has been a further miscommunication between the students and teachers or parents. A personal approach to children through art media is necessary and will help solve a lot of problems related to communication gaps.

The strategy that we need to take is to introduce art to children as early as possible. Dance, one of the branches of art, conveys symbolic, philosophical meanings, as well as historical values related to cultural issues that deserve to be put forward. As one of the branches of art, dance can be a medium for shaping children's behavior.

Strategies or techniques to introduce dance to children should be implemented because children tend to get bored of learning dance. Thus, dance teachers should fully understand what a dance is, how the dance is performed, whom is it for, and where dance is performed. These four principles are the basis of introducing dance to children. The provisional assumption that dance education is only about practices is unfounded because dance has a very complex historical background related to the cultural journey of a nation. Besides, teachers must be able to show that dance is one of the sources of education that is effective for children. Dance education is not aimed at teaching only the movements, but also attitudes, discipline.

Dewantara stated that arts will sharpen logical thinking, improve sensitivity, and develop a sense of independence [4]. Therefore, dance education can be a means of forming children's characters. Elementary school children tend to express themselves freely, so 
we need to teach them how to express themselves in the right way. In the future, when they are in junior and senior high schools, they will face no problems related to personal expressions. This makes dance education very important in life. In other words, music and dance are closely related to regular rhythm or rhythm which will have an impact on order and order in life, feelings of pleasure, and happiness. Dewantara also argues that teaching gending (music) or art is an effort to instill a sense of pride in the nation's beautiful and noble cultural wealth. The value learning proposed by Dewantara was an impact or benefit of learning art, values themselves were not directly planned to be taught.

In general, the purpose of providing dance material for children is to instill cultural values. Besides, it sharpens logical thinking, improves sensitivity, and develops a sense of independence. In particular, learning dance may be useful for children because through dances children may express their ideas and feelings. Moreover, through dance education, they are taught to be appreciative of arts. At last, this subject introduces basic movements to them although it does not teach children to become dancers, it builds their attitudes and characters through aesthetic senses, as well as symbolic and philosophical meanings based on Javanese values. With this awareness, dance education provides the right perspective on children's education towards a more competitive and global future.

\section{CONCLUSION}

Whatever the form of expression that teachers give to children to express themselves freely is the first step in shaping their personalities. Dance education for children at an early age will be able to filter the foreign country culture which is not in accordance with Indonesian characters. Children's behavior after adulthood is largely determined by the journey of life from childhood to elementary school. Therefore, it becomes clear that the mission of learning dance is not just learning body movements but learning to understand feelings with the philosophy of beauty contained in dances. Although dance education in elementary schools is currently very concerning or still underestimated, dances will not vanish as long as humans still exist. For this reason, art teachers in elementary schools must remain optimistic in delivering the future of their children with their respective abilities. The hyperreality that still exists will not prevent teachers to keep on teaching dances. It is expected that teachers are aware that dance education is related not only to practices but also to contexts that play important roles in shaping students' characters.

The problem of how the future strategy to provide awareness to prospective teachers and teachers to understand the concept of dance comprehensively can be solved by non-formal education or dance studios. The dance types and materials suitable for students can also be delivered by those dance studios. By knowing the characteristics of students, the orientation of the needs of the work is not just selective, although it is true that it is contextually needed and has positive implications for students. Relying on a learning approach that can be used to shape children's attitudes while practicing the dances seems to be more effective in instilling character values.

After the stages of the learning process are understood, the impacts of learning dances are shown by attitudes outside the class. This correlation is important to identify the ability to adopt dances based on nature to technology, based on animation to real dance, and vice versa. Thus, efforts to improve students' willingness to search for digital information related to dances may be done. Then, the expected result may not be in the form of hyperreality but reality.

\section{REFERENCES}

[1] Azwar, Muhammad. Hiperrealitas [Hyperreality]. 2014. State Islamic University (Departement of Library Science). Thesis. (unpublished).

[2] Black, F. B. Democratic practices as manifested through character education. Pearl, Art \& Pryor, Caroline R. Democratic. Eds. Practices in Education: Implication for Teacher Education (2005).

[3] Bourdieu, Pierre. The logic of practice. Stanford university press, 1990.

[4] Dewantara, Ki Hadjar. Bagian II Kebudayaan [Part II Culture]. Yogyakarta, Majelis Luhur Persatuan Tamansiswa (1994).

[5] Dewantara, Ki Hadjar. Bagian pertama pendidikan [The first part of education]. Yogyakarta: Percetakan Taman Siswa (1977).

[6] Dewantara, Ki Hadjar. Karya KH Dewantara bagian pertama Pendidikan (kumpulan karangan) [KH Dewantara's work is the first part of Education (a collection of essays).]. Yogyakarta: Majelis Luhur Persatuan Tamansiswa (2004).

[7] Kuswarsantya. Hubungan Antara Keterampjlan Seni Tari Gaya Yogyakarta dan Perjlaku Sopan Satun Siswa Sekolah Dasar TN Ibu Pawiyatan Taman Siswa Yogyakarta [The Relationship Between Yogyakarta-Style Dance Skills and the Polite Behavior of Satun Elementary School Students at TN Ibu Pawiyatan Taman Siswa Yogyakarta:]. 1991. IKIP Yogyakarta, Undergraduate Thesis. (Unpublished).

[8] Masunah, Juju. Konsep dan praktik pendidikan multikultural di amerika serikat dan Indonesia 
[Multicultural education concepts and practices in the United States and Indonesia]. Jurnal Ilmu $\begin{array}{lll}\text { Pendidikan } & 17.4 & \text { (2011). }\end{array}$ 10.17977/jip.v17i4.2732

[9] Muljono,Untung, Tari Anak untuk Pendidikan Karakter [Children's Dance for Character Education]. Seminar Naasional Pendidikan Seni Tari [National Seminar on Arts Education Seminar], 27 Nov. 2016, FBS UNY. Seminar.

[10] Murgiyanto, Sal. Ketika cahaya merah memudar: sebuah kritik tari [When the red light fades: a dance criticism]. Deviri Ganan, 1993.

[11] Murgiyanto, Sal. Tradisi dan inovasi: beberapa masalah tari di Indonesia [Tradition and innovation: some of the problems of dance in Indonesia]. Wedatama Widya Sastra, 2004.

[12] Pearl, Art, and Caroline R. Pryor. Democratic Practices in Education: Implications for Teacher Education. Rowman \& Littlefield Publishing Group, 4501 Forbes Blvd., Suite 200, Lanham, MD 20706, 2005.

[13] Piliang, Yasraf Amir. Medan Kreativitas: Memahami Dunia Gagasan [The Field of Creativity: Understanding the World of Ideas]. Yogyakarta: Cantrik Pustaka (2018).

[14] Royce, Anya Peterson. Antropologi Tari, terjemahan FX Widaryanto [Anthropology of Dance, translated by FX Widaryanto]. Bandung: Sunan Ambu Press STSI Bandung (2007). 